\title{
Diversity in athlete's response to strength effort in normobaric hypoxia
}

\section{Serum DSC study}

\author{
Anna Michnik $^{1}$ (i) $\cdot$ Zofia Drzazga $^{1} \cdot$ Izabela Schisler $^{1} \cdot$ Stanisław Poprzęcki ${ }^{2} \cdot$ Miłosz Czuba $^{3}$
}

Received: 31 October 2017 / Accepted: 10 February 2018/Published online: 19 February 2018

(C) The Author(s) 2018. This article is an open access publication

\begin{abstract}
The hypoxia may be used during exercise training sessions in humans with the aim of improving athletic performance. The effect of normobaric hypoxia strength training on thermal properties of blood serum has been evaluated in a group of 12 male and female athletes using differential scanning calorimetry (DSC). Each athlete was tested under normoxic and simulated hypoxic $\left(4000 \mathrm{~m}, \mathrm{~F}_{\mathrm{i}} \mathrm{O}_{2}=13 \%\right.$ and $\left.5000 \mathrm{~m}, \mathrm{~F}_{\mathrm{i}} \mathrm{O}_{2}=11.3 \%\right)$ conditions during squats with a barbell ( $\left.70 \% 1 \mathrm{RM}\right)$ exercise. A substantial inter-individual variation in the effects of hypoxia on serum DSC curves has been observed. The effect of exercising in normobaric hypoxia has been found greater for men than for the women. When the work intensity is high enough, the strength exercise in hypoxia can trigger an acute-phase response. Calorimetric and biochemical data have shown that men's exercising in hypoxia could increase the concentration of acute-phase proteins: haptoglobin and/or C-reactive protein. Our results suggest that 24-h period of rest is sufficient to return to the pre-exercise state after normoxic as well as hypoxic training session for both men and women. The recovery seems to be faster after the training in normobaric hypoxia conditions than in normoxia in the male but not in the female group of athletes.
\end{abstract}

Keywords Differential scanning calorimetry (DSC) $\cdot$ Exercise $\cdot$ Human blood serum $\cdot$ Hypoxia $\cdot$ Hypoxic training

\section{Introduction}

The concept of altitude or hypoxic training is a common practice since 40 years for improving sport performance. During this time, several strategies of such training regimens have been proposed, like "live high-train high" (LH$\mathrm{TH}$ ), "live high-train low" (LH-TL) or "intermittent

Anna Michnik

anna.michnik@us.edu.pl

1 Department of Medical Physics, A. Chełkowski Institute of Physics, The Silesian Centre for Education and Interdisciplinary Research, University of Silesia in Katowice, ul. 75 Pułku Piechoty 1A, 41-500 Chorzow, Poland

2 Department of Physiological and Medical Sciences, Department of Biochemistry, The Jerzy Kukuczka Academy of Physical Education in Katowice, ul. Mikołowska 72a, 40-065 Katowice, Poland

3 Department of Physiology, Institute of Sport, ul Trylogii 2/16, 01-982 Warsaw, Poland hypoxic training" (IHT). Recently, most attention is given to IHT that is considered the effective method of developing aerobic [1] and anaerobic [2] capacity. In this method, athletes live under normoxic conditions and train in a natural hypobaric or simulated normobaric hypoxic environment. The improvement in sport performance after IHT is mostly associated with non-hematological adaptive mechanisms [3] to hypoxia. The results of our previous study [3] and other well-controlled studies [4, 5] indicate that the improvements in aerobic capacity and endurance performance are caused by muscular and systemic adaptations, which are either absent or less developed after training under normoxia. The systemic hypoxia during the training process may cause more pronounced adaptive changes in muscle tissues than after traditional endurance training under normoxic conditions. These changes include increased fiber cross-sectional area, skeletal muscle mitochondrial density and elevated capillary-to-fiber ratio $[6,7]$. 
Though the different hypoxic training methods have gained popularity recently [8], scientific debate continues into whether the hypoxic training has any performance benefit for athletes [9-11]. A number of research projects have failed to demonstrate the improvement in sea level performance after IHT [9, 12-14]. Further research is necessary to explain the mechanisms involved in muscle hypertrophy during resistance training under hypoxic conditions. Moreover, it has been suggested that hypoxic training sessions appear to require longer recovery periods compared to normoxic training [15]. The review published by Flaherty et al. [16] provides an overview of potential problems which an athlete may experience at altitude.

Some authors examined the effect of normobaric hypoxia on maximal oxygen uptake $\left(\mathrm{VO}_{2 \max }\right)$ and maximal power $P_{\max }$ output during the exercise. In acute hypoxia, the decline of $\mathrm{VO}_{2 \max }$ was observed [17-19]. The trained athletes experienced greater reductions in $\mathrm{VO}_{2 \max }$ while exercising in acute hypoxic conditions compared to untrained subjects. This is consistent with greater pulmonary diffusion limitations to $\mathrm{VO}_{2 \max }$ for trained than untrained athletes during maximal exercise. Angermann et al. [20] have reported that $\mathrm{VO}_{2 \max }$ and $P_{\max }$ were affected differently by acute normobaric hypoxia corresponding to $3200 \mathrm{~m}$. Their another important finding was that athletes with high muscle capillarity and high muscle mitochondrial density are more susceptible to hypoxia. According to the results of Ofner et al. [18], participants with higher $\mathrm{VO}_{2 \max }$ in normoxia demonstrated a more pronounced reduction of this parameter in hypoxia in absolute terms as well as relative to $P_{\max }(r=-0.76$, $p<0.05)$. Lately, meta-regression analysis conducted by MacInnis et al. [21] on 105 independent groups of participants ( $n=21958$ subjects from 80 different studies) showed that $\mathrm{VO}_{2 \max }$ decreases as altitude increases and that the decrease is greater in individuals with higher aerobic capacities. There are, however, studies, where a significant increase in $\mathrm{VO}_{2 \max }$ has been observed after IHT, e.g., in well-trained cyclists and basketball players [3, 22].

In current study, athletes were exposed to normobaric hypoxia only during exercise sessions. In this situation, the potentially negative effects related to the exposure to high altitude could be avoided. The exercises performed in normoxia and normobaric hypoxia at simulated altitudes of 4000 and $5000 \mathrm{~m}$ above the sea level were separated by 7 days. The effect of hypoxia was evaluated using differential scanning calorimetry (DSC) method. Blood serum profiles of temperature heat capacity changes were analyzed and compared for athlete's performed squats with a barbell in normoxia and in a hypoxic training cycle.

The modern DSC was shown recently as valuable, harmless tool for disease diagnosis. This method enables to distinguish any slight differences between thermodynamic parameters of cancer and non-cancer diseases and norm [23-31]. Our earlier DSC studies [32, 33] of athlete's serum indicate that this technique may be also applied in sports medicine to support sports training.

\section{Materials and methods}

\section{Participants of the experiment}

Twelve active students of the Academy of Physical Education practicing strength sports participated in a research experiment, including 6 males (mean \pm SD: age $24.1 \pm 1.0$ year, mass $82.9 \pm 15.2 \mathrm{~kg}$, high $175.5 \pm 7.5 \mathrm{~cm}$ and BMI $25.6 \pm 3.8 \mathrm{~kg} \mathrm{~m}^{-2}$ ) and 6 females (mean \pm SD: age $24.5 \pm 1.5$ year, mass $67.6 \pm 13.2 \mathrm{~kg}$, high $162.5 \pm 2.5 \mathrm{~cm}$, and BMI $24.9 \pm \mathrm{kg} \mathrm{m}^{-2}$ ). All athletes were informed about the purpose and the nature of the research before giving their written consent to participate in the experiment. The studies were performed in accordance with the ethical standards of the responsible committee on human experimentation (institutional and national) and with Declaration of Helsinki. The study protocol was approved by the Ethics Committee of the Jerzy Kukuczka Academy of Physical Education in Katowice (Certificate of approval No. 4/2011).

\section{Experiment design}

Initially, the maximal load 1RM (1-repetition maximum) was measured in normoxic and hypoxic (4000 and $5000 \mathrm{~m}$ above the sea level) conditions using the device Myotest with test Half-Squat Profile. The exercise test was carried out in: (1) normoxic conditions (NORM), corresponding to the level of the sea and fraction of inspired oxygen $21 \%$, (2) normobaric hypoxia HYP4-4000 $\mathrm{m}$ above the sea level where the oxygen content was $13 \%$, (3) normobaric hypoxia HYP5-5000 $\mathrm{m}$ above the sea level where the oxygen content was $11.3 \%$. All tests were performed in normobaric hypoxia chamber. Normobaric hypoxia conditions were obtained with the climate system LOSHYP_1/3 NU (LOVOGEN SYSTEMS, Germany). The experiment comprised three stages in a 7-day interval. The participants of our experiment performed squats with a barbell with individual weight (70\% 1RM) in each environmental condition. They performed 10 sets of 10-12 repetitions with 5-min rest period between sets. Participants entered the exercise test after a $24-\mathrm{h}$ rest period.

\section{Blood serum samples}

Blood samples from each participant were obtained at approximately the same time of the day under experimental 
(normoxic or hypoxic) condition. Blood were collected at four time points: at rest (before the exercise- "be"), $3 \mathrm{~min}$ after the exercise ("ae"), after $1 \mathrm{~h}$ ("r1h") and $24 \mathrm{~h}$ ("r24h") of passive recovery. In normoxia and in HYP5 blood was collected from only 10 participants. Samples were obtained in a seated position from antecubital vein using Vacutainer system to draw blood into $2 \times 4 \mathrm{~mL}$ tubes containing no additives. Serum was obtained by centrifugation at $3500 \mathrm{rpm}$ for $10 \mathrm{~min},\left(4^{\circ} \mathrm{C}\right)$. Blood samples were assayed for albumin, $\alpha_{1^{-}}, \alpha_{2^{-}}, \beta$ - and $\gamma$ globulins. Serum from one tube was used to separate and to assay the contents of the major serum protein fractions using the device Minicap the Sebia capillary electrophoresis system and Minicap Protein (E) 6 kit. Serum samples were stored at $-20{ }^{\circ} \mathrm{C}$ before analysis. For DSC experiment, serum was diluted 20-fold with distilled degassed water. The $\mathrm{pH}$ value of the diluted samples has been within the range 6.5-7.0.

\section{DSC experiment}

DSC measurements were taken on the VP DSC MicroCal instrument (Northampton, MA) in the temperature range 20-100 ${ }^{\circ} \mathrm{C}$ with the heating rate $1{ }^{\circ} \mathrm{C} \min ^{-1}$. A constant pressure of about 1.8 atm was exerted on the liquids in the cells. The calorimetric data were corrected for the instrumental baseline water-water. DSC curves were normalized for the gram mass of protein, and next a linear baseline was subtracted. An apparent excess specific heat capacity $\mathrm{Cp}^{\mathrm{ex}}$ $\left(\mathrm{J}^{\circ} \mathrm{C}^{-1} \mathrm{~g}^{-1}\right)$ versus temperature $\left({ }^{\circ} \mathrm{C}\right)$ has been plotted.

The following parameters of observed DSC transitions have been determined: temperatures of local peak maxima $T_{\mathrm{m}}(m=1,2,3)$, excess specific heat capacities at these temperatures $\mathrm{Cp}_{\mathrm{m}}$, the enthalpy $(\Delta H)$ of serum denaturation (calculated as the area under the endothermic peak, expressed in $\mathrm{J} \mathrm{g}^{-1}$ ) and the width of peak in its half-height (HHW).

\section{Statistical analysis}

Statistical analysis was performed using the Statistica 13 software. For all measures, descriptive statistics were calculated. The Shapiro-Wilk test was used to check the normality of distributions of the studied variables. The homogeneity of variances in analyzed groups was verified by Leven's test. Student's $t$ test was used to compare the mean values between the two independent groups (men and women). Analysis of variance (ANOVA) with the period of training cycle as a repeated measure and the group or training conditions as categorical variables was used. If repeated measures ANOVA was statistically significant, Tukey's post-hoc test was applied. The level of statistical significance was set at $p<0.05$, results with $p<0.1$ were interpreted as tendencies.

Pearson's correlation coefficients were found to describe the relationships between biochemical and thermodynamic blood serum parameters.

\section{Results}

DSC curves of blood serum acquired before a training in normoxia have been averaged in the men and women groups of participants. Such mean DSC melting profiles for both groups are shown in Fig. 1. The observed complex endothermic transition represents the weighted sum of heat capacity changes connected with the thermal denaturation of the individual proteins within serum thus serum DSC curves give information about the thermodynamic stability of the most abundant serum proteins. Similar curves were presented and discussed by us earlier for aqueous solutions of serum derived from male amateur cyclists [32] and athletes who performed CrossFit [33]. The intensities of three visible local maxima $\left(T_{1}, \mathrm{Cp}_{1}\right),\left(T_{2}, \mathrm{Cp}_{2}\right),\left(T_{3}, \mathrm{Cp}_{3}\right)$ have been found correlated with the level of: (1) albumin fatless fraction and $\alpha$-2 globulins, (2) $\alpha$-1- and $\alpha$-2-globulins, (3) $\beta$-and $\gamma$-globulins, respectively. Thus, an increase or decrease in component peaks intensity may be linked to changes in various protein fractions.

The shapes of the blood serum heat capacity profiles presented in this and earlier works [32, 33] for athletes serum diluted with distilled water $(\mathrm{pH}$ 6.5-7.0) are distinctly different from serum/plasma profiles reported for healthy persons where the final $\mathrm{pH}$ of solutions was in the range 7.2-7.5 [23-27, 30]. The main origin of discussed differences is probably the thermal denaturation profile of fatty acid-free fraction of albumin. DSC transition representing unfolding of unligated albumin was shown much

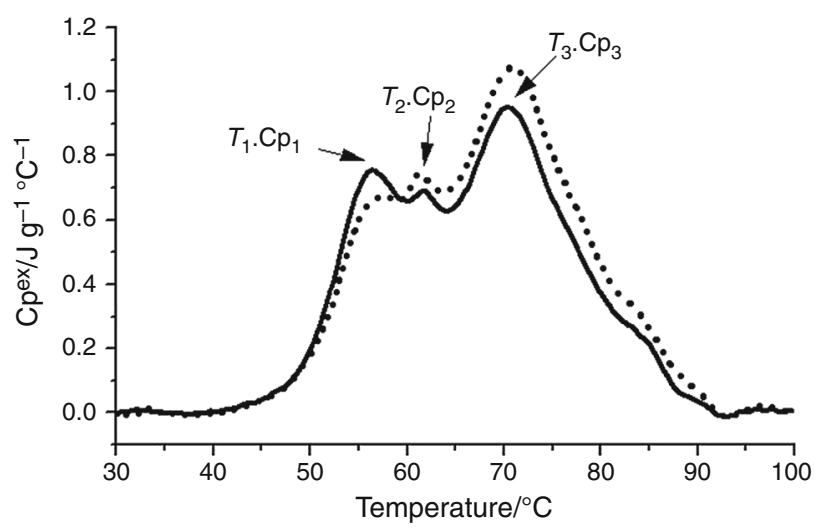

Fig. 1 Mean DSC curves (the excess specific heat capacity as a function of temperature) of pre-exercise serum coming from men (solid line) and women (dot line) in normoxic conditions 
sharper in buffer ( $\mathrm{pH}$ 7.2) than in water $(\mathrm{pH}$ 6.5) solution (see Fig. 1a in Ref. [34]). The advantage of DSC profiles observed for aqueous serum solutions (with $\mathrm{pH}$ below the physiological value) is the separation of contributions from albumin and haptoglobin.

The comparison of serum DSC curves shown in Fig. 1 indicates differences in the relation of component peaks observed for men and women participated in our study. The $\mathrm{Cp}_{3} / \mathrm{Cp}_{1}$ ratio is significantly higher $(p=0.02)$ for women $(1.60 \pm 0.19)$ than for men $(1.27 \pm 0.17)$. This ratio reflects to some extent globulins to albumin proportion in serum. Data shown in Table 1 indicate that there are no meaningful differences in the mean level of globulins fractions between male and female participants. At the beginning of the experiment, the mean level of albumins and $A / G$ ratio were higher for men than for women but differences were not statistically significant, probably due to a small number of participants and a great individual variability, which was observed in our experiment. In hypoxic conditions the opposite tendency in $A / G$ changes was observed depending on gender: an increase in the $A /$ $G$ ratio for women and its decrease for men in comparison with normoxia.

Figures 2 and 3 illustrate mean DSC curves of serum taken before the exercise ("be"), after the exercise ("ae"), after an hour of rest ("r1h") and $24 \mathrm{~h}$ of rest ("r24h") in a group of men at NORM and in a group of women at simulated hypoxic conditions $5000 \mathrm{~m} \quad\left(\mathrm{~F}_{\mathrm{i}} \mathrm{O}_{2}=11.3 \%\right)$, respectively. In both figures, only the curve after $1 \mathrm{~h}$ of rest clearly stands out from the others. Thus, it can be supposed that the effect of strength exercise is reflected in the serum with a delay. So, it is better visible in DSC curves after a short recovery period than immediately after the effort. Hypoxic conditions modify the difference between " $1 \mathrm{~h}$ " and "be" DSC curves. It decreases with increasing simulated altitude for men while for women the opposite tendency has occurred. Moreover, a slight increase in $\mathrm{Cp}_{1}$, the intensity of peak corresponding mainly to unligated albumin, can be observed directly after the exercise for men (see Fig. 2) but not for the women (see Fig. 3). Similar finding refers to the training in other conditions also (data not shown).

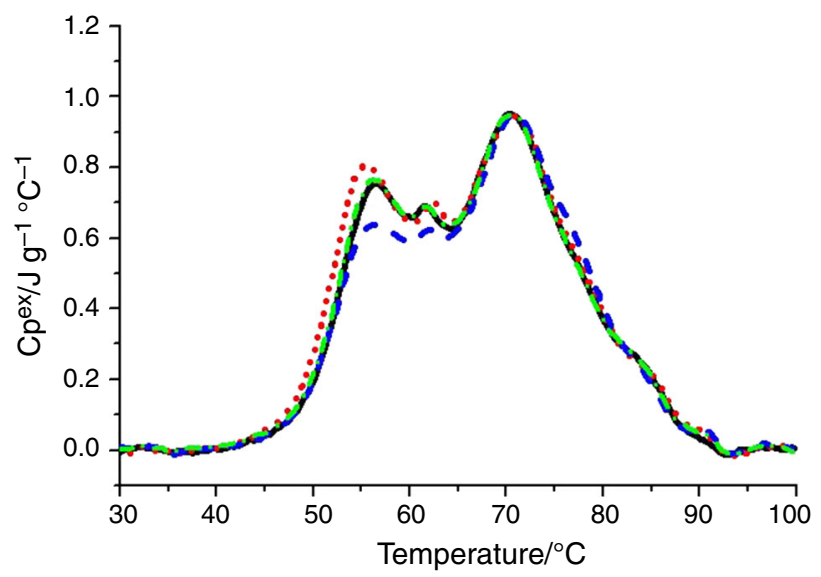

Fig. 2 Mean DSC curves of serum taken before exercise (solid line), after exercise (dot line), after an hour of rest (dash line) and $24 \mathrm{~h}$ of rest (dash-dot line) in a group of men in normoxic conditions

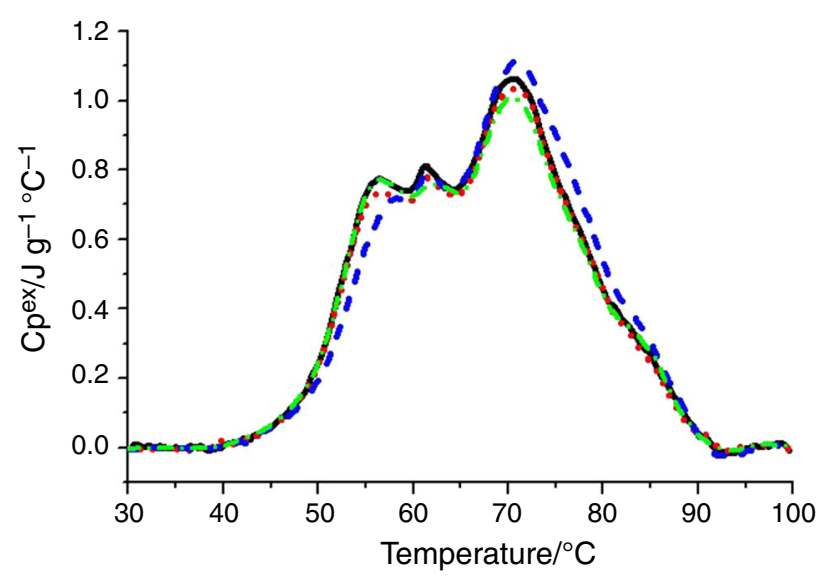

Fig. 3 Mean DSC curves of serum taken before exercise (solid line), after exercise (dot line), after an hour of rest (dash line) and $24 \mathrm{~h}$ of rest (dash-dot line) in a group of women at simulated hypoxic conditions HYP5

The set of mean DSC curves for women's serum after the exercise in NORM, HYP4 and HYP5, shown in Fig. 4, suggests that the direct effect of exercise performed by women does not depend on training conditions. Practically, there are no changes connected with hypoxic conditions in comparison with NORM in presented mean melting
Table 1 Mean concentrations of the serum protein fractions $( \pm \mathrm{SD})$ and albumins to globulins ratio $(A / G)$ for participants at the beginning and at the end of training cycles

\begin{tabular}{|c|c|c|c|c|}
\hline & \multicolumn{2}{|l|}{ Women } & \multicolumn{2}{|l|}{ Men } \\
\hline & "be" NORM & "r24h" HYP5 & "be" NORM & "r24h" HYP5 \\
\hline Albumin/g L ${ }^{-1}$ & $41.3 \pm 3.1$ & $44.7 \pm 2.9$ & $45.1 \pm 2.7$ & $43.2 \pm 4.2$ \\
\hline$\alpha-1$ globulins/g L ${ }^{-1}$ & $2.6 \pm 0.9$ & $2.1 \pm 0.2$ & $2.0 \pm 0.3$ & $2.4 \pm 0.5$ \\
\hline$\alpha-2$ globulins/g L ${ }^{-1}$ & $5.5 \pm 1.1$ & $5.1 \pm 0.8$ & $5.4 \pm 0.6$ & $7.2 \pm 2.3$ \\
\hline$\beta$-globulins/g L $\mathrm{L}^{-1}$ & $10.0 \pm 1.7$ & $9.0 \pm 0.9$ & $9.3 \pm 1.1$ & $10.2 \pm 1.3$ \\
\hline$\gamma$-globulins/g L ${ }^{-1}$ & $12.1 \pm 2.3$ & $11.1 \pm 2.4$ & $12.9 \pm 1.9$ & $12.0 \pm 2.1$ \\
\hline$A / G$ & $1.39 \pm 0.16$ & $1.65 \pm 0.21$ & $1.53 \pm 0.09$ & $1.39 \pm 0.29$ \\
\hline
\end{tabular}




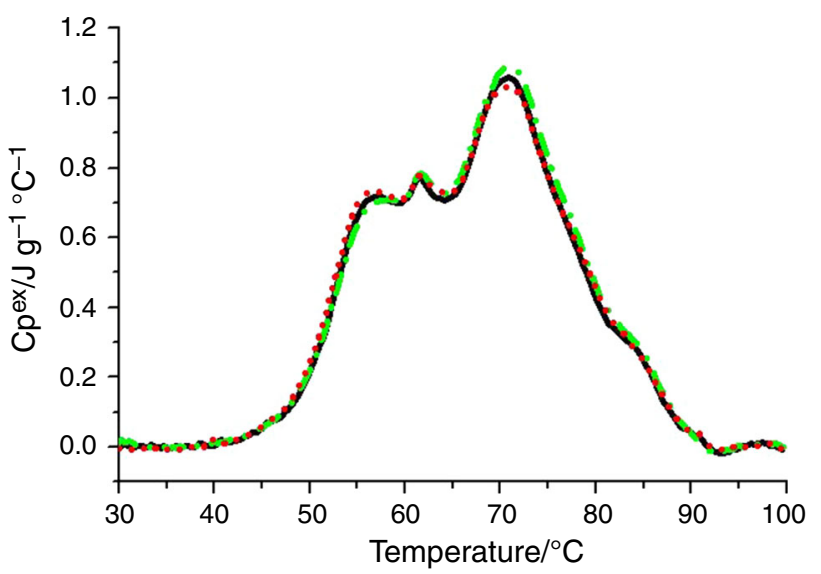

Fig. 4 Mean serum DSC curves for women after the exercise in normoxia (solid line), HYP4 (dash line) and HYP5 (dot line)

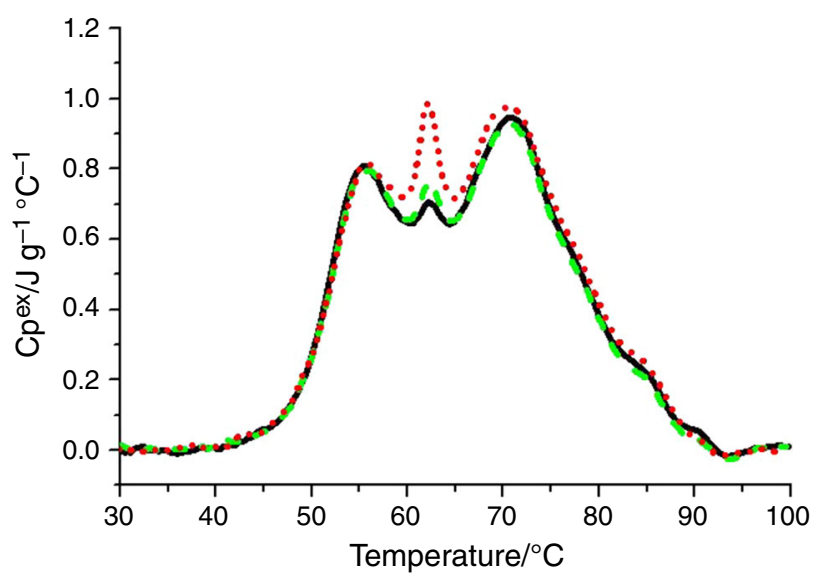

Fig. 5 Mean serum DSC curves for men after the exercise in normoxia (solid line), HYP4 (dash line) and HYP5 (dot line)

profiles of post-exercise woman's serum. Generally, the mean response of women to hypoxia seems to be hardly noticeable.

Unlike, the set of mean curves presented in Fig. 5 for post-exercise men's serum indicates clear changes connected with hypoxic conditions. A significant increase in $\mathrm{Cp}_{2}$ intensity with increasing altitude is well visible, especially in HYP5. A characteristic, sharp peak giving the main contribution to the local maximum $\left(T_{2}, \mathrm{Cp}_{2}\right)$ comes from haptoglobin $(\mathrm{Hp})$, the acute-phase protein belonging to $\alpha-2$ globulins fraction. The thermal denaturation profile of Hp has been shown in the Supplement to [23] by Garbett et al. Even at relatively low concentration in serum, haptoglobin gives a significant, specific contribution to the serum denaturation DSC profile [23]. The level of this acute-phase protein (APP) may increase in any inflammatory process (infection, extreme stress, burns, major crush injury, etc.). In particular, intensive increase in $\mathrm{Cp}_{2}$ value in response to hypoxic conditions has been observed for two men who performed 10 series of 12 squats with $90-\mathrm{kg}$ barbells (the largest weight, because the man who was going to do this with $120-\mathrm{kg}$ barbell did not finish the task). Probably, in the case of these two men exercise in hypoxia was enough to produce exercise-induced acutephase response that resulted in marked increase in serum concentration of haptoglobin. The elevated value of $\mathrm{Cp}_{2}$ has been observed for these athletes also before the exercise in HYP5 conditions, 7 days after the training in HYP4. It suggests keeping up an elevated level of $\mathrm{Hp}$ due to the earlier exhaustive exercises in hypoxia, what is in agreement with a dynamics of $\mathrm{Hp}$ concentration changes in serum [35].

It should be said, that substantial inter-individual variation in the effects of hypoxia on men's response to exercising has been observed. Figure 6 illustrates quite different trend of post-exercise serum DSC profile changes associated with increasing altitude than the average one shown in Fig. 5. For this athlete the most significant change concerns the first local maximum $\left(T_{1}, \mathrm{Cp}_{1}\right)$. Although this maximum is connected mainly with unligated albumin, the observed increase in $\mathrm{Cp}_{1}$ can not be explain by an increase in the level of this most abundant serum protein in this case. The post-exercise concentration of albumin in serum of said man was $47.0 \mathrm{~g} \mathrm{~L}^{-1}$ in normoxia, $46.9 \mathrm{~g} \mathrm{~L}^{-1}$ in HYP4 and $43.3 \mathrm{~g} \mathrm{~L}^{-1}$ in HYP5. Thus, an increase in unligated fraction of albumin may be suggested. The collected biochemical data have shown a slight increase in $\alpha_{2^{-}}$and $\beta$-globulins occurred for considered example in hypoxic conditions. The most significant increase has been observed in $\gamma$-globulins concentration: from $11.8 \mathrm{~g} \mathrm{~L}^{-1}$ in normoxia to $13.3 \mathrm{~g} \mathrm{~L}^{-1}$ in HYP4 and $14.0 \mathrm{~g} \mathrm{~L}^{-1}$ in HYP5. DSC curves shown in Fig. 6 indicate that the levels of immunoglobulins, which give a contribution to the peak with maximum $\left(T_{3}, \mathrm{Cp}_{3}\right)$, do not rise. Because the $\gamma$-globulin fraction includes also

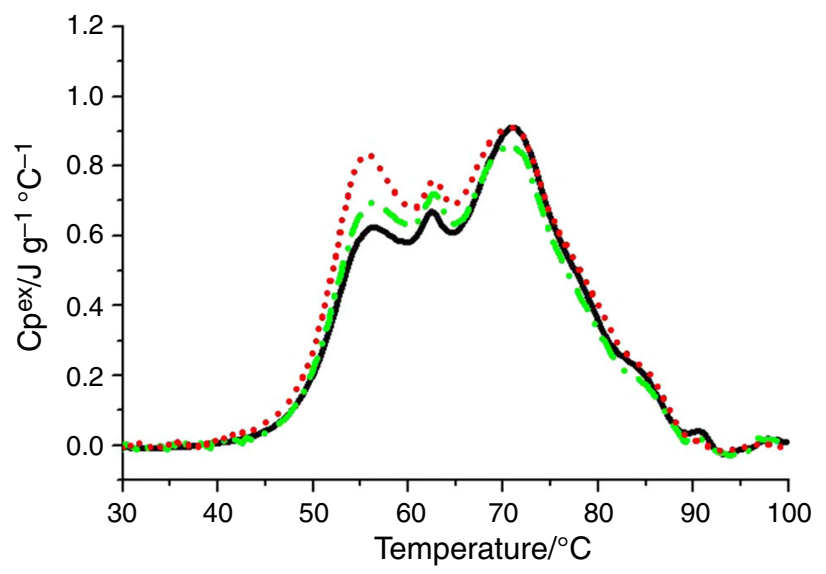

Fig. 6 An example of the uncommon effect of exercising in hypoxia: NORM (solid line), HYP4 (dash-dot line) and HYP5 (dot line) 
C-reactive protein (CRP), the overall increase in $\gamma$-globulins level may be due to an increase in this acute-phase protein. According to Supplemental Fig. 1 presented by Garbett et al. [23], CRP thermal denaturation transition takes place in the temperature range $50-68{ }^{\circ} \mathrm{C}$. So, the increase in $\mathrm{Cp}_{1}$ intensity in hypoxic conditions, visible in Fig. 6, may be partly explained by the increase in CRP concentration in serum. It has been concluded that strength exercising in hypoxia could elevate the level of acute-phase proteins (Hp and/or CRP) in the group of men.

All mean DSC curves corresponding to pre-exercise serum and after $24 \mathrm{~h}$ of rest (an examples can be seen in Figs. 2, 3) are very similar. So, our results indicate that hypoxic training sessions do not require longer recovery periods compared to normoxic training. The $24 \mathrm{~h}$ period of rest is sufficient to return to the pre-exercise state for both men and women. However, some differences between men and women can be observed after the short 1-h rest depending on the hypoxic conditions. In a group of men differences between serum DSC curves before the exercise and after $1 \mathrm{~h}$ of rest decline with altitude increase. In normobaric hypoxia at a simulated altitude of $5000 \mathrm{~m}$ mean DSC curves before the exercise, after $1 \mathrm{~h}$ of rest and after $24 \mathrm{~h}$ of rest are practically the same (data not shown). These results suggest that for men the recovery after hypoxic training session is faster than after the normoxic training.

The opposite effect of hypoxia on differences between DSC curves after $1 \mathrm{~h}$ of rest and before the exercise can be observed for women. Differential curves shown in Fig. 7 indicate that these differences increase with increasing altitude in the female group. The clear minimum in the temperature range $50-60{ }^{\circ} \mathrm{C}$, accompanied by the maximum in the temperature range $70-80{ }^{\circ} \mathrm{C}$ is well visible for women who trained in HYP5 conditions. As no significant

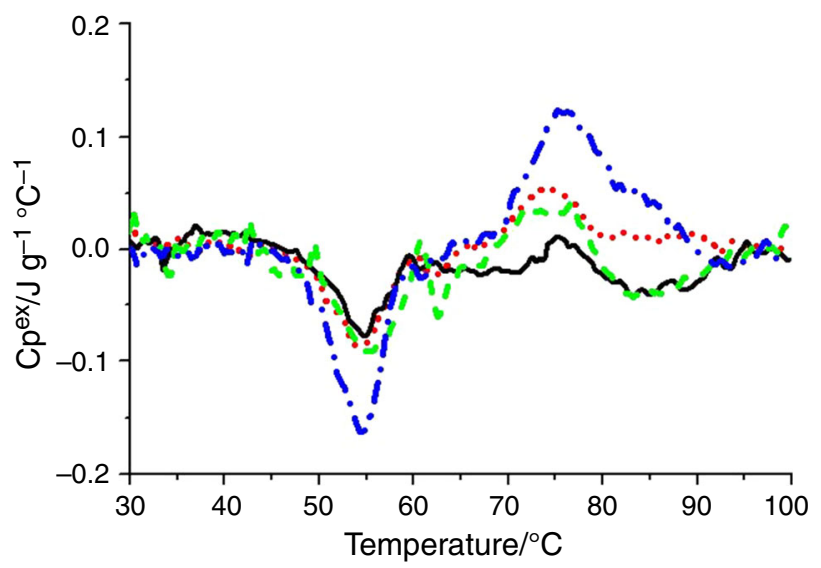

Fig. 7 Differential DSC curves (differences between DSC curves after $1 \mathrm{~h}$ of rest and before the exercise) for women who trained in NORM (solid line), HYP4 (dash line), HYP5(dash-dot line) and for men who trained in HYP4 (dot line) changes have been found in mean values of albumin as well as globulins levels between "be" and "rlh" periods for women in our study, the shape of the described HYP5 differential curve does not result from changes of these proteins concentration. The suggested explanation may be connected with changes in the proportion of different albumin forms: unligated and carrying different ligands. Various forms of albumin unfold in different temperature ranges, e.g., the denaturation of fatty acid-free albumin molecules proceeds in much lower temperatures than the denaturation of non-defatted albumin [36, 37]. The decline of unligated form to increase the ligands bounded form of albumin $1 \mathrm{~h}$ after the completion of the exercise in HYP5 training can explain the shape of curves shown in Fig. 7. It is worth noting that at HYP4 conditions differential curves for men and women are very similar.

The analysis of the level of serum proteins fractions as well as thermodynamic parameters describing serum thermal transition has shown that most of these parameters are practically independent of the stage of training cycle ("be", "ae", "r1h" and "r24h") and hypoxic conditions (NORM, HYP4, HYP5). Exceptions are $\alpha_{2}$-globulins level and $\mathrm{Cp}_{2}$ value in the male participants group. Mean values of $\alpha_{2}$-globulins concentration in serum of athletes are shown in Fig. 8 at different times of the normoxic and hypoxic training cycle. Similar dependences for $\mathrm{Cp}_{2}$ values are presented in Fig. 9. A marked increase in $\alpha_{2}$-globulins level as well as $\mathrm{Cp}_{2}$ with simulated extreme altitude is well visible for male athletes. Statistical analysis showed significant differences between $\alpha_{2}$-globulins concentrations in NORM, HYP4 and HYP5 conditions $(p=0.04)$ while for $\mathrm{Cp}_{2}$ parameter only the tendency was found $(p=0.07)$. A slight increase in the mean $\alpha_{2}$-globulins concentration is also noticeable after the exercise for men as well as for women in all training conditions. Results of ANOVA with the period of training cycle as a repeated measure indicate that $\alpha_{2}$-globulins concentrations changes are statistically significant in NORM $(p=0.01)$ and in HYP5 $(p=0.003)$ conditions. The post hoc Tukey's test pointed to "ae" $\div$ "r1h" $(p=0.006)$ difference in NORM and "be" $\div$ "ae" $(p=0.01)$, "ae" $\div$ "rlh" $(p=0.006)$, "ae" $\div$ "r24h" $(p=0.008)$ differences in HYP5.

A large similarity which is evident in the course of changes shown in Figs. 8 and 9 for $\alpha_{2}$-globulins concentrations and $\mathrm{Cp}_{2}$ parameter, respectively, indicates that our DSC results are in accordance with biochemical data. A very high, statistically significant correlation has been found between the $\mathrm{Cp}_{2}$ intensity and $\alpha_{2}$-globulins levels. The highest one (Pearson's correlation coefficient $r=0.94$ ) has occurred for men after exercise.

Among proteins from $\alpha_{2}$-globulins fraction, especially important when interpreting the DSC results, is haptoglobin. As haptoglobin is an acute-phase protein, any 
Fig. 8 The level of $\alpha_{2}$-globulins in serum of athletes in different times of the hypoxic training cycle: before the exercise (be), after the exercise (ae), after $1 \mathrm{~h}$ (r1h) and $24 \mathrm{~h}(\mathrm{r} 24 \mathrm{~h})$ of passive recovery

Fig. 9 Mean values of $\mathrm{Cp}_{2}$ for NORM, HYP4 and HYP5 conditions in different times of the hypoxic training cycle

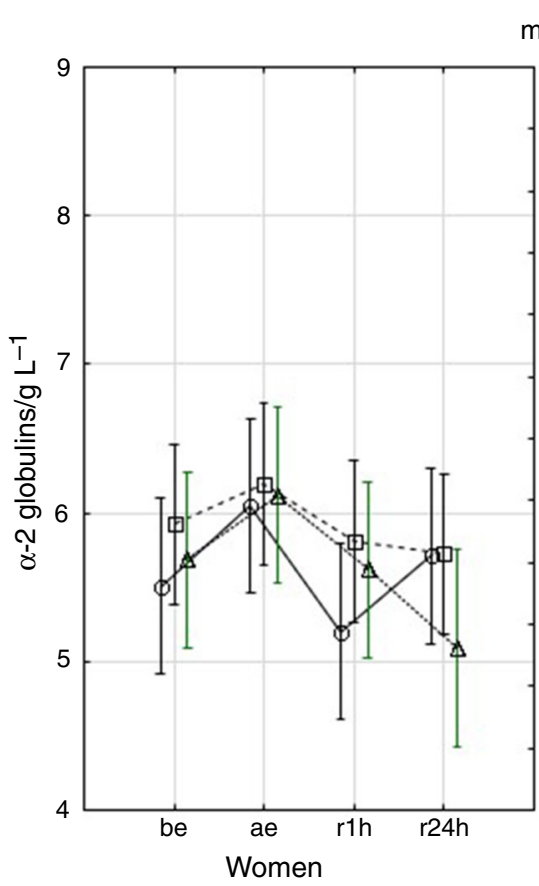

mean $\pm S D$
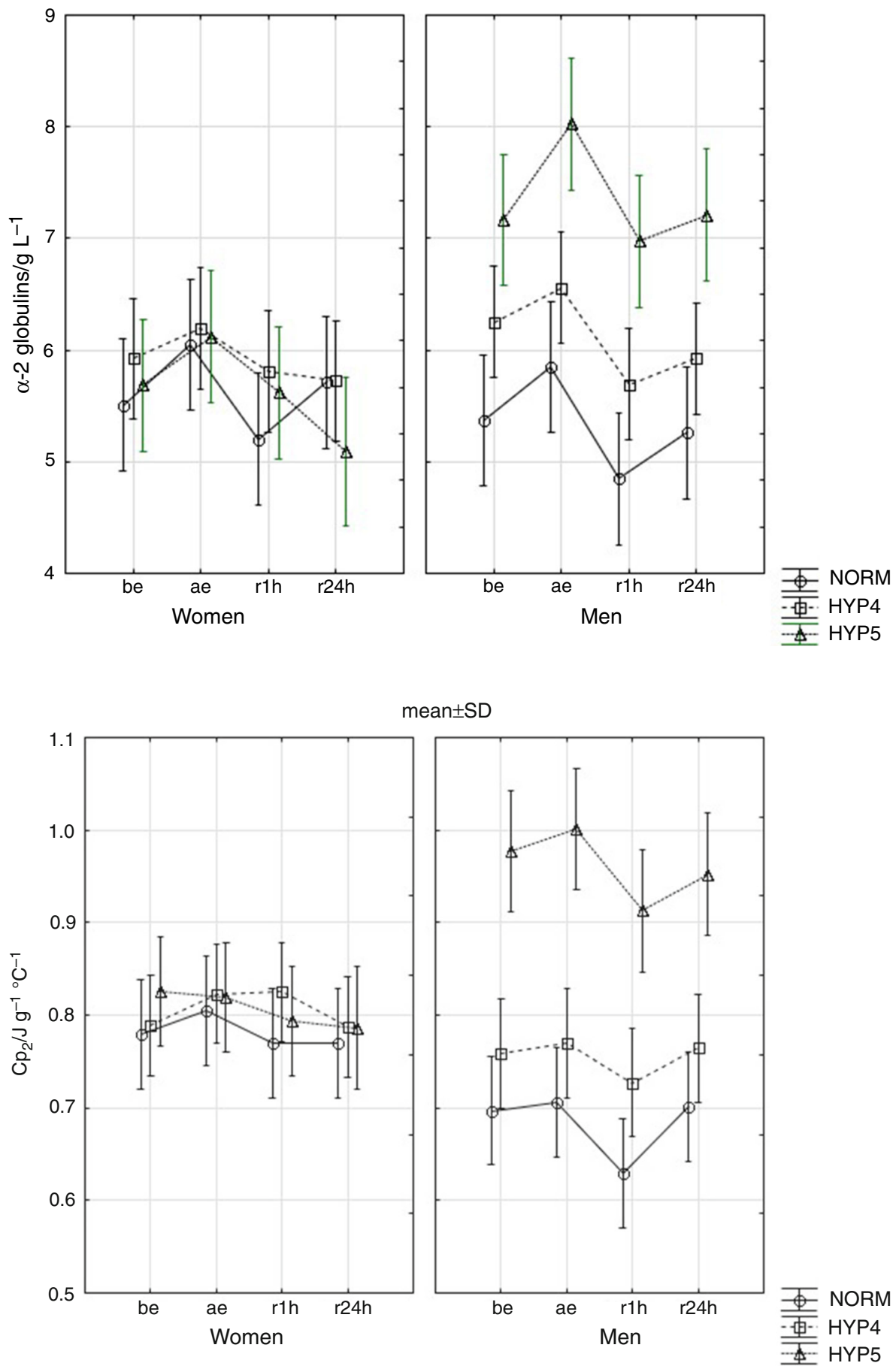

inflammatory process (infection, extreme stress, burns, major crush injury, etc.) may significantly increase the levels of plasma haptoglobin. It has been reported that the inflammatory symptoms experienced after high intensity exercise are similar to those seen during chronic disease [38]. An increase in serum APPs (CRP, Hp, serum amyloid A) after prolonged exercise was reported in humans $[38,39]$ and animals (mice, dogs) [39, 40]. Since Hp is an extremely potent antioxidant [41], Chen et al. [39] have suggested that elevated Hp expression level may potentially play a protective role reducing the oxidative stress during the exercise.

Recent studies indicate that high levels of plasma Hp is advantageous in patients with acute respiratory distress syndrome [39]. The relationship between $\mathrm{VO}_{2 \max }$ and $\mathrm{Cp}_{2}$ intensity has been suggested by us recently [33]. In current 
study, in particular intensive increase in $\mathrm{Cp}_{2}$ value connected with an increase in $\alpha_{2}$-globulins in response to hypoxic conditions has been observed for two men repeated bouts of exercise with the largest weight. The reduced ability of fitter elite athletes to train at altitude due to limitations in their pulmonary gas exchange system at high work rates [42] may be considered as the cause of such observation. It is in agreement with finding that highly trained endurance athletes suffer more severe gas exchange impairments during acute exposure to hypoxia than untrained individuals [17]. Unfortunately, we do not have the $\mathrm{VO}_{2 \max }$ values for athletes participated in this study.

In athletes, the changes in serum DSC at rest and after exercise could be an important training tool for coaches and clinicians. The scope of these changes depends of the training load during the exercise and a level of hypoxia. Additionally, we also observed a varied change in the recovery period after different training sessions (different level of hypoxia) in the study. DSC results suggests that this method can be used as a marker of assessing fatigue during weekly training program (microcycle) to individualized training loads. The fatigue induction during sport training is the first rule of the training adaptation process to improve athlete performance by stimulating organism functions. The balance between stress and recovery factors defines the quality of the training program, and observation of this state is necessary for effective training process and prevents overtraining. The results of this study indicate the need for more individualized programming of the training. The time has come not only for personalized medicine, but also for personalized training, which provides athletes safety and success.

\section{Conclusions}

It is believed that intermittent hypoxic training IHT would potentiate greater performance improvements compared to similar training at sea level. The effectiveness of hypoxic training to improve performance, however, varied among different sports [3, 43]. Increased hypoxic stress at altitude facilitates key physiological adaptations within the athlete and could increase the training stimulus. However, it is widely accepted that prolonged exposure to extreme altitude is detrimental for muscle structure. Moreover, hypoxia impairs $\mathrm{O}_{2}$ delivery, which decreases one's maximal oxygen uptake $\mathrm{VO}_{2 \max }$ relative to normoxia. Highly trained subjects seem to suffer more under hypoxic conditions than untrained people. Generally, an individual response to the altitude should be expected, and our results confirm this statement.

A substantial inter-individual variability has been observed in the effects of hypoxia on DSC curves of athlete's serum. The exhaustive exercise in hypoxia has induced probably an acute-phase response in some cases. Particularly, in mail group an increase in haptoglobin and/ or C-reactive protein concentrations in serum has occurred due to the intensive hypoxic training. The effect of exercising in normobaric hypoxia at a simulated altitude of 4000 and $5000 \mathrm{~m}$ has been found greater for men than for the women. Some opposite trends have emerged depending on gender, e.g., an increase in albumin/globulin ratio for women and a decrease in this ratio for men at $5000 \mathrm{~m}$ in comparison with normoxia. Our results indicate also that hypoxic training sessions do not require longer recovery periods compared to normoxic training. The recovery process after the men's training in simulated normobaric hypoxia has been suggested to be even faster than in normoxia.

Open Access This article is distributed under the terms of the Creative Commons Attribution 4.0 International License (http://creative commons.org/licenses/by/4.0/), which permits unrestricted use, distribution, and reproduction in any medium, provided you give appropriate credit to the original author(s) and the source, provide a link to the Creative Commons license, and indicate if changes were made.

\section{References}

1. Czuba M, Fidos-Czuba O, Płoszczyca K, Zając A, Langfort J. Comparison of the effect of intermittent hypoxic training vs. the live high, train low strategy on aerobic capacity and sports performance in cyclists in normoxia. Biol Sport. 2018;35:39-48. https://doi.org/10.5114/biolsport.2018.70750.

2. Czuba M, Wilk R, Karpiński J, Chalimoniuk M, Zajac A, Langfort J. Intermittent hypoxic training improves anaerobic performance in competitive swimmers when implemented into a direct competition mesocycle. PLoS ONE. 2017;12(8):e0180380. https://doi.org/10.1371/journal.pone.0180380.

3. Czuba M, Waskiewicz Z, Zając A, Poprzecki S, Cholewa J, Roczniok R. The effects of intermittent hypoxic training on aerobic capacity and endurance performance in cyclists. J Sports Sci Med. 2011;10:175-83.

4. Dufour SP, Ponsot E, Zoll J, Doutreleau S, Lonsdorfer-Wolf E, Geny B, Lampert E, Flück M, Hoppeler H, Billat V, Mettauer B, Richard R, Lonsdorfer J. Exercise training in normobaric hypoxia in endurance runners. I. Improvements in aerobic performance capacity. J Appl Physiol. 2006;100:1238-48.

5. Zoll J, Ponsot E, Dufour S, Doutreleau S, Ventura-Clapier R, Vogt M, Hoppeler H, Richard R, Fluck M. Exercise training in normobaric hypoxia in endurance runners. III. Muscular adjustments of selected gene transcripts. J Appl Physiol. 2006;100:1258-66.

6. Desplanches D, Hoppeler H, Linossier MT, Denis C, Claassen H, Dormois D, Lacour JR, Geyssant A. Effects of training in normoxia and normobaric hypoxia on human muscle ultrastructure. Pflüg Arch. 1993;425:263-7.

7. Vogt M, Puntschart A, Geiser J, Zuleger C, Billeter R, Hoppeler H. Molecular adaptations in human skeletal muscle to endurance training under simulated hypoxic conditions. J Appl Physiol. 2001;91:173-82. 
8. Álvarez-Herms J, Julià-Sánchez S, Hamlin MJ, Corbi F, Pagès T, Viscor G. Popularity of hypoxic training methods for endurancebased professional and amateur athletes. Physiol Behav. 2015;143:35-8.

9. Morton JP, Cable NT. Effects of intermittent hypoxic training on aerobic and anaerobic performance. Ergonomics. 2005;48:1535-46.

10. Flaherty G, O'Connor R, Johnston N. Altitude training for elite endurance athletes: a review for the travel medicine practitioner. Travel Med Infect Dis. 2016;14:200-11.

11. Lundby C, Robach P. Does 'altitude training' increase exercise performance in elite athletes? Exp Physiol. 2016;101(7):783-8.

12. Truijens MJ, Toussaint HM, Dow J, Levine BD. Effect of highintensity hypoxic training on sea-level swimming performances. J Appl Physiol. 2003;94:733-43.

13. Ventura N, Hoppeler H, Seiler R, Binggeli A, Mullis P, Vogt M. The response of trained athletes to six weeks of endurance training in hypoxia or normoxia. Int $\mathbf{J}$ Sports Med. 2003;24:166-72.

14. Roels B, Bentley DJ, Coste O, Mercier J, Millet GP. Effects of intermittent hypoxic training on cycling performance in welltrained athletes. Eur J Appl Physiol. 2007;101:59-368.

15. Vogt M, Hoppeler H. Is hypoxia training good for muscles and exercise performance? Prog Cardiovasc Dis. 2010;52:525-33.

16. Flaherty G, O'Connor R, Johnston N. Altitude training for elite endurance athletes: a review for the travel medicine practitioner. Travel Med Infect Dis. 2016;14:200-11.

17. Lawler J, Powers SK, Thompson D. Linear relationship between $\mathrm{VO}_{2 \max }$ and $\mathrm{VO}_{2 \max }$ decrement during exposure to acute hypoxia. J Appl Physiol. 1988;64:1486-92.

18. Ofner M, Wonisch M, Frei M, Tschakert G, Domej W, Kröpfl JM, Hofmann P. Influence of acute normobaric hypoxia on physiological variables and lactate turn point determination in trained men. J Sports Sci Med. 2014;13:774-81.

19. Martin D, O'Kroy J. Effects of acute hypoxia on the $\mathrm{VO}_{2}$ max of trained and untrained subjects. J Sports Sci. 1993;11:37-42.

20. Angermann M, Hoppeler H, Wittwer M, Dapp C, Howald H, Vogt M. Effect of acute hypoxia on maximal oxygen uptake and maximal performance during leg and upper-body exercise in Nordic combined skiers. Int J Sports Med. 2006;27:301-16.

21. MacInnis MJ, Nugent SF, MacLeod KE, Lohse KR. Methods to estimate $\mathrm{VO}_{2 \max }$ upon acute hypoxia exposure. Med Sci Sports Exerc. 2015;47:1869-76.

22. Czuba M, Zając A, Maszczyk A, Roczniok R, Poprzecki S, Garbaciak W, Zajac T. The effects of high intensity interval training in normobaric hypoxia on aerobic capacity in basketball players. J Hum Kinet. 2013;39:103-14.

23. Garbett NC, Miller JJ, Jenson AB, Chaires JB. Calorimetry outside the box: a new window into the plasma proteome. Biophys $\mathrm{J}$. 2008;94:1377-83.

24. Garbett NC, Mekmaysy CS, Helm W, Jenson AB, Chaires JB. Differential scanning calorimetry of blood plasma for clinical diagnosis and monitoring. Exp Mol Pathol. 2009;86:186-91.

25. Michnik A, Drzazga Z, Michalik K, Barczyk A, Santura I, Sozańska E, Pierzchała W. Differential scanning calorimetry study of blood serum in chronic obstructive pulmonary disease. J Therm Anal Calorim. 2010;102:57-60.

26. Todinova S, Krumova S, Gartcheva L, Robeerts Ch, Taneva SG. Microcalorimetry of blood serum proteome: a modified interaction network in the multiple myeloma case. Anal Chem. 2011;83:7992-8.

27. Todinova S, Krumova S, Kurtev P, Dimitrov V, Djongov L, Dudunkov Z, Taneva SG. Calorimetry-based profiling of blood plasma from colorectal cancer patients. Biochim Biophys Acta. 2012;1820:1879-85.

28. Fekecs T, Zapf I, Ferencz A, Lőrinczy D. Differential scanning calorimetry (DSC) analysis of human plasma in melanoma patients with or without regional lymph node metastases. J Therm Anal Calorim. 2012;108:149-52.

29. Moezzi M, Fekecs T, Zpf I, Ferencz A, Lőrinczy D. Differential scanning calorimetry (DSC) analysis of human plasma in different psoriasis stages. J Therm Anal Calorim. 2013;111:1801-4.

30. Garbett NC, Mekmaysy CS, DeLeeuw L, Chaires JB. Clinical application of plasma thermograms. Utility, practical approaches and considerations. Methods. 2015;76:41-50.

31. Ferencz A, Lörinczy D. DSC measurements of blood plasma on patients with chronic pancreatitis and operable and inoperable pancreatic adenocarcinoma. $\mathrm{J}$ Therm Anal Calorim. 2017; 127:1187-92.

32. Michnik A, Drzazga Z, Poprzęcki S, Czuba M, Kempa K, Sadowska-Krępa E. DSC serum profiles of sportsmen. J Therm Anal Calorim. 2013;113:365-70.

33. Michnik A, Sadowska-Krępa E, Domaszewski P, Duch K, Pokora I. Blood serum DSC analysis of well-trained men response to CrossFit training and green tea extract supplementation. J Therm Anal Calorim. 2017. https://doi.org/10.1007/s10973-017-6346-9.

34. Michnik A, Drzazga Z. Thermal denaturation of mixtures of human serum proteins-DSC study. J Therm Anal Calorim. 2010;101:513-8.

35. Szutowicz A, Raszeia-Specht A. Diagnostyka laboratoryjna, tom II. Copyright by Medical University of Gdańsk (ISBN 978-83602537-7-9); 2011.

36. Michnik A. Thermal stability of bovine serum albumin DSC study. J Therm Anal Calorim. 2003;71:509-19.

37. Michnik A, Michalik K, Kluczewska A, Drzazga Z. Comparative DSC study of human and bovine serum albumin. J Therm Anal Calorim. 2006;84:113-7.

38. Fallon KE. The acute phase response and exercise: the ultramarathon as prototype exercise. Clin J Sport Med. 2001;11:38-43.

39. Chen CY, Hsieh WL, Lin PJ, Chen YL, Mao SJT. Haptoglobin is an exercise-responsive acute-phase protein, acute phase proteinsregulation and functions of acute phase proteins, Prof. Francisco Veas, editor (ISBN: 978-953-307-252-4). InTech; 2011. http:// www.intechopen.com/books/acute-phase-proteins-regulationand-functions-of-acute-phaseproteins/. Accessed 10 Nov 2015.

40. Tharwat M, Al-Sobayil F, Buczinski S. Influence of racing on the serum concentrations of acute-phase proteins and bone metabolism biomarkers in racing greyhounds. Vet J. 2014;202:372-7.

41. Tseng CF, Lin CC, Huang HY, Liu HC, Mao SJT. Antioxidant role of human haptoglobin. Proteomics. 2004;4:2221-8.

42. Powers SK, Martin D, Dodd S. Exercise-induced hypoxaemia in elite endurance athletes. Incidence, causes and impact on $\mathrm{VO}_{2 \max }$. Sports Med. 1993;6:14-22.

43. Hinckson EA, Hamlin MJ, Wood MR, Hopkins WG. Game performance and intermittent hypoxic training. Br J Sports Med. 2007;41(8):537-9. 